NIKOLA MIJATOV, MA, Research Assistant

Institute of Contemporary History

Belgrade, Republic of Serbia

nikolamijatov@gmail.com

UDK: 32:929 Ђилас М.(093.2)

originalan naučni rad

primljeno: 29. maj 2018.

prihvaćeno: 20. mart 2019.

https://doi.org/10.29362/ist20veka.2019.2.mij.217-238

\title{
THE CASE OF MILOVAN DJILAS AND THE EUROPEAN SOCIALISTS 1954-1958*
}

ABSTRACT: This paper analyzes the consequences of the dissidence of Milovan Djilas on relations between Yugoslavia and the European socialists. With the case of Djilas, relations between the parties of the Socialist International gradually deteriorated to their lowest point in 1958. This paper also analyzes the use of the Djilas case by the European socialists as a specific instrument of diplomatic pressure on Yugoslavia.

KEYWORDS: Milovan Djilas, European Socialists, Dissidence, New Class

For Yugoslavia, the parties of the European Left were crucial in the process of emerging from the blockade of the Cominform and making alliances with the West. ${ }^{1}$ The bridge to the West was built chiefly with the help of the British Labourists, and a new foreign policy was established, which was, in effect, shortlived. They went even further, as the socialists of Western Europe were aiming to make relations even more complex than simply intergovernmental; in that aspect, inter party cooperation was the form for the further improvement of relations.

The complex task of making connections and cooperation with the European socialists was assigned primarily to Milovan Djilas and Vladimir Dedijer. Between 1950 and 1954 they made Yugoslavia a part of the European Left, which rallied around the Socialist International, by establishing dynamic cooperation with these parties.

\footnotetext{
* This article is part of the project Conflicts and crises: cooperation and development in Serbia and in the region in the 19th and 20th century (47030) that is financed by the Ministry of Education, Science and Technological Development of the Republic of Serbia.

${ }^{1}$ In the paper by the term "European left" parties of labour, socialist and social democratic type in Western Europe is used for easier systematization. And even though the term is not correct: the left should primarily consider Communist parties, Trockyists and anarchistic movements, this term was often used in the correspondence between the Communist party of Yugoslavia and the mentioned parties. Paradoxically, the communist parties, and the conservative fractions within them (in the sense of Marxism-Leninism), was called right-wing.
} 
However, with new ideological turbulences it was Djilas (and initially also Dedijer) who demanded changes to Social Democracy in Yugoslavia itself. These turbulences were significant having in mind that Yugoslavia had complex bilateral relations with each of the countries with whose Socialists Djilas and Dedijer had established relations. Taking this into account, the case of Milovan Djilas and the events of the Third Party Plenum with its ensuing persecutions, could not have passed unnoticed among the European socialists.

\section{The "New Thought" and its Condemnation}

It all started with the article "New forms" ("Novi oblici"), ${ }^{2}$ with which this distinguished member of the Politburo, Peoples hero, and prominent leader of 1948, stepped onto the path of dissidence and open conflict with the system that he himself had established.

The main issue was his criticism of the one-party system, a criticism that pierced into the essence of revolutionary Yugoslavia. In a total of 18 articles, from the idea of communism he came close to the idea of social democracy, opposing the very purpose of the "dictatorship of the proletariat": "The goal, today, briefly, is to enable the fastest and least painful shift toward socialism, an enhancement of democracy, through concrete achievable forms, and not through communism or the like." 3

The criticism came from the top of the government itself, and represented a call for change. Based on the decisions of the VI Party Congress, Djilas suggested forming a new party. In a conversation with Kardelj, he proposed a labor type party. ${ }^{4}$ The stated was most likely a consequence of his close relations with the British labourists, firstly with Aneurin Bevan. ${ }^{5}$ Nevertheless, the causes of the articles by Djilas were very complex; a hidden motive for his call for a multiparty system could have been purely ideological, foreign political, or even an attempt to remain in power. As such, the causes of his dissidence demand a separate study.

Paradoxically, the criticism that started the fire was not the one targeting the regime, or his call for another party, but the criticism of the personal life of a friend from the party. In an article entitled "Anatomy of a Morality" ("Anatomija jednog morala") by analyzing the behavior of Milena, the wife of Peko Dapčević, Djilas showed the existence, or the emergence, of the same bourgeois morality against which the partisans had fought. A party trial followed: in January of 1954 the Third Party Plenum of the Central Committee of

\footnotetext{
${ }^{2}$ Милован Ђилас, Пад нове класе: повест о саморазарағу комунизма (Београд: Службени лист СРЈ, 1994), 147.

${ }^{3}$ Borba, 8. 12. 1954.

${ }^{4}$ Vladimir Dedijer, Veliki buntovnik Milovan Đilas: prilozi za biografiju (Beograd: Prosveta, 1991), 377.

${ }^{5}$ More about the relations of Milovan Djilas and the British labourists before the dissidence in: Vladimir Unkovski-Korica, "The Yugoslav Communists' Special Relationship with the Britih Labour Party 1950-1956”, Cold War History vol 14, no. 1, (2014), 23-46; Nikola Mijatov, „Milovan Đilas i britanski laburisti 1950-1955“, Istorija 20. veka br. 2, (2015), 27-43.
} 
the League of Communists of Yugoslavia (CC LCY) was convened, with one topic on the agenda - Milovan Djilas.

Relations between Djilas and the European socialists were one of the key topics at the Plenum. Given the fact that its transcripts were completely published in Borba and Politika, the consequences were inevitable. ${ }^{6}$ Tito himself used his speech at the Plenum to address the position of Yugoslavia toward the West: "... not to mention the reaction of the West, which thinks that he carries the banner of our party." Aleš Bebler noted that the possible cause was the visit to India and the significance that was attributed to him "probably in England"... "I think that it has affected you Djido (nickname for Djilas - N. M.)." Then he said: "for the West you are a representative of 'freedom' tendencies and we are all representatives of 'dictatorship' tendencies." delivered by Petar Stambolić stands out because it directly invokes the words "workers-communist," pointing out that Djilas should not have been allowed to go abroad and that he had come under the influence of Bevan. ${ }^{8}$ Dedijer echoed Stambolic's observation even more directly: "Then open accusations were made that Aneurin Bevan was a social-democrat rogue, responsible for Djilas forsaking Communism and falling into a social-democratic revisionist trap.",

Djilas repented stating that his belief in Yugoslav socialism had been revived. Still, his punishment was inevitable; he was condemned for anarcholiberalism and revisionism, his articles were withdrawn, and he was expelled from the Central Committee (CC) and from all levels of party and state office. In addition to this, he was given a last warning.

Relations with the British labourists had suffered the most following the Plenum. Fact, the monthly review of the British Labour Party, celebrated the victory of labourism against self-management stating that now Yugoslavia could look upon the Labour Party as a "dangerous source of infection."10 Among the officials Bevan stands out, who, after the Plenum, did not visit the Yugoslav Embassy in London, despite formerly being a frequent guest. ${ }^{11}$ Only a few days after the Plenum, Tito received a letter from Bevan expressing his concern for Djilas and Dedijer. He referred to his involvement in the whole case: "Based on some remarks made by people of your country, who are in top government positions, I realized that it was felt that Milovan had formed his political views under my bad influence, and that our friendship had influenced his behavior." Also, he directly stated: "Nothing concerns me more that the well-being of Vlado (Dedijer $-\mathrm{N}$. M.), Milovan, and their families." However, in reply to this letter Tito ensured

${ }^{6}$ Borba, 18. 1. 1954; Вогba, 19. 1. 1954; Вогba, 20. 1. 1954; Политика 19. 1. 1954; Политика 28. 1. 1954.

${ }^{7}$ Arhiv Jugoslavije (AJ), fond 837, Kabinet predsednika Republike (KPR), Plenarne sednice CK KPJ 1948-1978 II/11, Izlaganje Aleša Beblera na Trećem plenumu.

${ }^{8}$ Branislav Kovačević, Dilas heroj-antiheroj: iskazi za istoriju (Podgorica: Pobjeda, 2006), 475.

${ }^{9}$ V. Dedijer, Veliki buntovnik Milovan Đilas: prilozi za biografiju, 406.

10 AJ, fond 507, Centralni komitet Saveza komunista Jugoslavije (CK SKJ), IX, S/c-409-411, Komisija za međunarodne odnose i veze: Razno.

${ }^{11}$ AJ, 507, CK SKJ, IX, S/c-408, Komisija za međunarodne odnose i veze: Razno. 
Bevan that he thought that he had not influenced Djilas and that the personal freedom of Djilas would not be jeopardized. ${ }^{12}$ Jennie Lee also stepped in: while talking to secretary Knežević in the House of Commons she said she was surprised regarding Yugoslavia's sudden twist in relations with the West. The case itself she observed in an international context, in the light of the death of Stalin and the possibility of improving relations with the USSR. For Lee, the case was a clash with the leaders of progress and democracy with those opting for the USSR. ${ }^{13}$

Still, in his conversations with Burke, Phillips, Watson and Rose in February of 1954, Ambassador Petric understood what the background of the reaction of the British labourists was. The Labourists stated that the condemnation of Djilas had resulted in his expulsion at the VI Party Congress and that this was directly connected to the appointment of the Yugoslav ambassador in Moscow. Burke was direct, while the other party colleagues expressed their resentment: they had expected that Yugoslavia would steer further and further from the USSR and accept their views - the policy that was present in the last report of Charles Pick. ${ }^{14}$ Furthermore, they used the opportunity to protest against the condemnation of social democracy at the Plenum. ${ }^{15}$

Djilas's planned visit to Sweden, Norway, and Denmark was canceled. ${ }^{16}$ Djilas himself wrote to them stating that his position with the Socialist Alliance of the Working People of Yugoslavia (SAWPY) had changed significantly and that he would not represent opinions that the majority of the SAWPY leaders would not support. Kardelj also wrote to them. ${ }^{17}$ The Norwegians reacted, stating that Djilas had only implemented the decisions of the VI Congress. On the one hand, the Swedish socialists disapproved Djilas's actions and his ideas, which, according to Björk and Aspling, would lead Yugoslavia into anarchy. They directly supported a oneparty system but had also seen the treatment of Djilas as a discrepancy from the

${ }^{12}$ Vladimir Dedijer, Veliki buntovnik Milovan Đilas: prilozi za biografiju, 378, 379.

${ }^{13} \mathrm{AJ}, 837$, KPR, II-4-a/116, Izveštaji, informacije, beleške, pisma i pisanje štampe o slučaju Milovana Đilasa.

${ }^{14}$ Charles Pick was the ambassador of Great Britain in Yugoslavia. In his last report from Belgrade from 16. October 1951 he stated: "Because of that I think that any attempt to speed up the turn of Yugoslavia into some sort of liberal social democracy would lead only to that that marshal Tito like a porcupine will show his quills of independence. Yugoslav Government will despite the slow, painful and often unsuccessful process, come to point where it will its politics and practice bring closer to British role models. I repeat that, in my opinion, this process will probably be very long (Darko Bekić, Jugoslavija u Hladnom ratu: Odnosi sa velikim silama 1949-1955. (Zagreb: Globus, 1988), 336).

${ }^{15}$ Diplomatski arhiv Ministarstva spoljnih poslova Republike Srbije (DA MSP), Politička arhiva (PA), 1954, Engleska, f-20, 314/a, Razgovori naših predstavnika u Engleskoj: Zabeleška o razgovoru druga ambasadora J. Petrića sa pretsednikom I. O. Laburističke partije Vilfred Burkeom, sekretarom Morgan-om Filips-om, pretsednikom spoljno-političkog komiteta Sam Vatsonom i načelnikom spoljno-političkog komiteta Saul Rose-om, na večeri 10. februara 1954.

${ }^{16}$ More about the canceled visit to Sweden, Norway and Denmark in: Aleksandar V. Miletić, "Unrealised Nordic Dream': Milovan Đilas and the Scandinavian Socialsts", Tokovi istorije, br. 3, (2015), 89-106.

${ }^{17}$ AJ, 837, KPR, II-4-a/116, Izveštaji, informacije, beleške, pisma i pisanje štampe o slučaju Milovana Đilasa: Informacija Spoljno-političke komisije SSRNJ 16. 2. 1954. 
USSR. Relations with these parties had significantly improved after a successful visit by Kardelj and Bakarić in October $1954 .{ }^{18}$ On the other hand, the socialists of Denmark were insulted because of the cancellation of the visit, but that had more to do with the bad relations between the two parties than with Djilas himself. ${ }^{19}$

Nevertheless, the character of the Plenum, its free and public discussion, had a positive echo. For the Dutch labourist-majority Naters, it was a clear distinction from the Soviet methods while for prominent German socialist Ollenhauer, the Plenum was proof of the "firmness and the new spirit of the Yugoslav party". ${ }^{20}$

With the Dutch Labor Party, the situation was more complex. ${ }^{21}$ Its officials visited Yugoslavia in September of 1954. The visit was specific because its results were mainly negative. In an article published in Het Patrol they stated that Yugoslavia was a dictatorship in which there was no freedom. The visit and its consequences were not the result of the Djilas case, for which the officials did not have any not particular interest, but in fact only represented the continuity of bad relations between two parties. ${ }^{22}$ Returning from Sweden and Norway, Kardelj and Bakarić also briefly visited the Netherlands, where their Labor party officials were completely passive and avoided any meetings or contacts, and by so doing, continued the bad relations with the SAWPY, on which the Plenum had no significant influence. ${ }^{23}$

During the meeting of the Bureau of the Socialist International, at an informal lunch that followed, the topic was Djilas. Julius Braunthal, secretary of the International, stated that the majority was hostile toward the Plenum. Braunthal himself stated that he did not support Djilas and that the hostile attitude of his colleagues was due to their lack of knowledge of Marxism. ${ }^{24}$ Živko Topal-

18 DA MSP, PA, 1954, Norveška, f-64, 314/a, Razgovori naših predstavnika u Norveškoj: Zabeleška o razgovoru ministra R. Uvalića sa A. Andersen-om, 22. aprila 1954; DA MSP, PA, 1954, Švedska, f-90, 314/a, Razgovori naših predstavnika u Švedskoj: Zabeleška o razgovoru dr. Darka Černeja sa generalnim sekretarom švedskog MIP-a Anre Lundberg-om, održanim 6. februara 1954; DA MSP, PA, 1954, Norveška, f-64, 322, Političke posete.

19 The Danish Socialist Party was the most conservative among the socialist parties of Northern Europe. Nevertheless, Živko Topalović's reputation in it was strong. Relations with the SAWPY were not established up until 1955. (AJ, 507, SKJ, IX, S/a-19, Komisija za međunarodne odnose i veze: Sednice komisije 1950-1955).

20 DA MSP, PA, 1954, Holandija, f-31, 314/a, Razgovori naših predstavnika u Holandiji: Zabeleška o razgovoru druga Ristića sa Goes van Naters-om, članom rukovodstva Holandske partije rada, 22. januara 1954; DA MSP, PA, 1954, Nemačka, f-62, 314/a, Naši razgovori u Nemačkoj: Zabeleška o razgovoru Ambasadora FNRJ u Bonu, dr. Mladena Ivekovića sa prvacima SPD Olenauerom, Vehnerom i Neumanom, 13. februara 1954.

21 The Dutch Labor Party was known for its distinct conservativism and clericalism, unusual among the parties of the left. Despite this, Živko Topalović had strong support within this party (DA MSP, PA, 1953, Holandija, f-35, 122, Političke partije; DA MSP, PA, 1953, Holandija, f35, 314/a, Razgovori naših predstavnika u Holandiji: Razgovarao M. Ristić).

${ }^{22}$ DA MSP, PA, 1956, Holandija, f-23, 322, Političke posete.

${ }^{23}$ DAMSPRS, 1956, PA, Holandija, f-31, 322, Političke posete.

${ }^{24}$ AJ, 837, KPR, II-4-a/116, Izveštaji, informacije, beleške, pisma i pisanje štampe o slučaju Milovana Đilasa: Razgovor sekretara Kneževića sa Žulijus Brauntalom, sekretarom Socijalističke internacionale, 13. 2. 1954. 
ović $^{25}$ did not miss the opportunity to promote himself, stating that his position had significantly improved. He wrote two articles about Djilas, published in Sindikalist Exile. ${ }^{26}$

The SAWPY was not passive; its reaction was needed in order to restore Yugoslavia's damaged reputation. Visits to Belgium, Britain and France were made by Veljko Vlahović in order to assess their reactions to the case and also to present counterarguments. In Britain, he met with Phillips and Bevan. He characterized his conversation with Phillips as ,rather unfriendly" and his interlocutor as reserved. Phillips used the opportunity to express interest regarding Djilas and his fate. However, Vlahović encountered a much friendlier approach during his dinner with Bevan and Lee. Bevan was interested in Tito's reaction to his letter. Vlahović told him that Tito felt that this was not so much a political matter but rather an act of friendship between Bevan and Djilas. Bevan also stated that he supported Djilas's ideas about a multi-party system in Yugoslavia, but also said that it was surely not an issue of a power struggle but a struggle against bureaucracy, which, for him, was represented by Kardelj. When it came to political freedom, Bevan told Vlahović: "There is no freedom in a system that can remove a politician overnight and it is not democratic that people are agreeing with that removal." He was also interested to know where Djilas was living, whether he was working or not, and whether he or Dedijer could write letters to him or Lee. Also he expressed the desire to return his hospitality to Djilas and Dedijer and asked if they could spend their vacations in Britain. Vlahović said that it was their personal decision and that the government would not stand in their way. Vlahović also tried to explain the "meaning" of Stambolić's speech at the Third Plenum, but Bevan was not interested in any explanations. In his report at the end of his visit to Britain, Vlahović said that it was necessary to neutralize the actions of the Labourists as much as possible and especially to be careful if Bevan visited Yugoslavia because he would surely meet with Djilas. In France, Guy Mollet pointed out that he found Djilas's ideas appealing but if he were the leader of Yugoslavia, he would also support a single-party system. Vlahović ensured him that relations with the French socialists would not be impaired. The socialists of Belgium, where Djilas did not have any deeper influence, had a similar approach. He gave a lecture at the Vandervelde Institute, which had originally been planned for Djilas, and had a conversation with Julius Humbert-Droz, who stated that three years earlier he had seen "some negative moments in Djilas's discourse." Droz did not comment on the expulsion of Dedijer and changed the subject talking about the publishing of the new socialist magazine, asking only whether Dedijer would be replaced. Vlahović's conclusion from the trip was illustrative: "After all the con-

\footnotetext{
25 Živko Topalović was a pre-war social democrat, a collaborator of Draža Mihajlović during the war, and a political emigrant after the war. In Yugoslavia he was sentenced in absentia. As a representative of the Socialist Party of Yugoslavia in exile, he was a member of the European Socialists. He was also a member of the Socialist International and the Movement for European Unification.

${ }^{26}$ AJ, 837, KPR, II-4-a/116, Izveštaji, informacije, beleške, pisma i pisanje štampe o slučaju Milovana Đilasa: Stav Jugoslovenske političke emigracijeu vezi slučaja Đilas.
} 
versations that I had, I got the impression that the socialists need our support even more that we need theirs". 27

In addition to the reactions of the European socialists, the social democrats of Italy stand out. Because of the resolved Trieste issue, the main obstacle toward good relations had been eliminated. The Plenum had basically no reception in Italy, only in the press. First initiatives were made during October and November of 1954, when the officials of the Italian Social Democratic Party suggested an improvement of relations with the SAWPY, stating that such a policy was supported by the leader Giuseppe Saragat. ${ }^{28}$

\section{Suspended Sentence and its Reception in the West}

Despite the party verdict and warning, Djilas did not break off his relations with the labourists, nor his political activity, now in different circumstances. By the end of the summer of 1954 he met with British labourist Ernest Davis at Excelsior Hotel. The meeting itself was on Davis's initiative and his main interest were Djilas's political ideas. Furthermore, three articles by Djilas were to be published in the labourist paper Daily Herald. However, that did not happen because as Djilas said: "I did not receive the call so the articles were not published". Still, we have only one source regarding the articles - Djilas himself through his memoirs and transcripts from his trial in $1955 .^{29}$ In a British Embassy report we find only a short memo about Davis arriving in Yugoslavia for a brief visit, while the character and the aim of the visit were not disclosed. ${ }^{30}$ Therefore, we cannot be certain what exactly happened at the meeting. Soon afterwards, Djilas also met with a group of American youth, but that meeting did not leave any significant trace. ${ }^{31}$

The moment the anti-Yugoslav campaign eased up, the Djilas case got its new dynamic and the campaign intensified. In November of 1954 Dedijer was summoned before the CC LCY Control Commission for his conduct at the Third Plenum and his connections with Djilas after the Plenum. Djilas had promised to stand by Dedijer, which journalist Jack Raymond ${ }^{32}$ saw as an opportunity. ${ }^{33}$ Soon,

\footnotetext{
${ }^{27}$ AJ, 507, SKJ, IX, II/11, Plenarne sednice CK KPJ 1948-1978, Izveštaj o putu u Englesku, Belgiju i Francusku od 25. februara do 6. marta 1954. godine - Veljko Vlahović, 5.

${ }^{28}$ DA MSP, PA, 1954, Italija, f-37, 314/a, Razgovori naših predstavnika u Italiji: Zabeleška o razgovoru Žulj Berislava sa prof. Luigi Preti-em, poslanikom i članom direkcija PSDI i podsekretarom ministarstva državnog trezora, održanim 27. oktobra 1954; Zabeleška savetnika Perišića o razgovoru sa sekretarom PSDI, poslanikom M. Mateotiem, 10. novembra 1954.

${ }^{29}$ Milovan Đilas, Vlast (London: Naša reč, 1983), 287; Kosta Nikolić i Srđan Cvetković, Rađanje jeretika: suđenje Milovanu Đilasu i Vladimiru Dedijeru 1955 (Beograd: Institut za savremenu istoriju, 2011), 112.

${ }^{30}$ Yugoslavia: Political Diaries 1918-1965, vol. 4: 1949-1965, Edited by, R. L. Jarman (Oxford: Archive Editions, 1997), 573.

${ }^{31}$ M. Đilas, Vlast, 287.

${ }^{32}$ Raymond was more than a correspondent of The New York Times in Yugoslavia: he was the first journalist who interviewed Ranković and during Trieste crisis, often "informatively" made suggestions to Yugoslav officials. (AJ, 837, KPR, I-5-b/104-1).

${ }^{33}$ Ambassador Vodak states that Raymond asked Kardelj for an interview. When he was rejected,
} 
in December of 1954 in the New York Times, in an interview to Raymond, Djilas directly criticized the leading party officials and indicated the need for an opposition: "There should be a new political formation. It can only be democratic and socialist but in any case, it must not be a step back to the old discredited Yugoslav parties... I am a democratic socialist. The name communism is good but has been compromised." He also addressed the rumors regarding the eventual removal of Tito: "I did not organize any faction... I promised that the only solution could be democracy and not any Djilas program or any group against Tito. This country has had enough revolutions." 34 The same interview was offered to Belgium's Le Peuple, the voice of the socialists, but they did not want to publish it. ${ }^{35}$

The interview came, not by accident, in a specific situation in which Yugoslavia found itself at that moment. In the USSR a battle for the position of secretary general was raging and it had its impact on Yugoslavia. ${ }^{36}$ On the other hand, the West was aware of that and was pressuring Yugoslavia as well. The first signs of a possible reconciliation were visible with the appointment of ambassadors. At the peak of that struggle, Tito went on his Asia tour on his ship "Galeb," which deliberately made the journey long. His destination was India and Burma. The visit marked a definitive connection with the Third World and paved the way for the principle of Active Coexistence. ${ }^{37}$

It that moment, when a signal from Moscow was expected, while relations with the Third World were being build, an indictment was raised against Djilas and an trial was to follow, all observed by the West. A prominent Bevanist, Ian Mikardo stated that a suspended sentence would leave the best impression in the West. ${ }^{38}$ Bevanists came all the way to India where through Indian socialists Bevan and Lee had intervened with Tito. Austrian minister Vodak was direct: "Yugoslavia is about to take a delicate exam with its foreign policy and a well measured decision regarding Djilas will mean more than any other clear remarks of a non-existing alliance with the Soviets". 39

The trial was held on January 24, 1955, closed to public. During the trial, the connection with the European socialists could not remain unnoticed, Djilas had to defend himself: "I made my standpoints independently from them and

he asked Djilas. (AJ, 837, KPR, I-5-b/6-3, Zabeleška o razgovoru sa austrijskom ambasadorom Valterom Vodakom na večeri u njegovom stanu, 17. februara 1955. godine).

34 AJ, fond 513, Moše Pijade (MP), XXXIX MP, III-3/134, 1950-1955 - k. 24, Izgradnja nove Jugoslavije, 1944-1964, Slučaj Milovana Đilasa i Vladimira Dedijera, sa propratnim materijalom.

${ }^{35}$ AJ, 837, KPR, I-5-b/9-1, Jugoslavija-Belgija.

36 Михаил Гелер и Александар Некрич, Утопија на власти: историја Совјетског Савеза (Подгорица: ЦИД, 2000), 479-501.

${ }^{37}$ Ljubodrag Dimić, Jugoslavija i Hladni rat: Ogledi o spoljnoj politici Josipa Broza Tita (19441974), (Beograd: Arhipelag, 2014), 139; Dragan Bogetić, Koreni jugoslovenskog opredeljenja za nesvrstanost (Beograd: Institut za savremenu istoriju, 1990), 205.

${ }^{38}$ DA MSP, PA, 1955, Engleska, f-14, 314/a, Razgovori naših predstavnika u Engleskoj: Razgovor V. Velebita sa Ian Makard-om, 18. januara 1955.

39 AJ, 837, KPR, II-4-a/116, Izveštaji, informacije, beleške, pisma i pisanje štampe o slučaju Milovana Đilasa. Stav Jugoslovenske političke emigracije u vezi slučaja Đilas. 
I independently represent them". 40 The punishment was inevitable, but its character is illustrative: Djilas got an 18-month suspended prison sentence. Dedijer got a 6-month suspended sentence. A suspended sentence at that moment practically was the perfect balance between East and West. After the trial, Djilas said: "This verdict is great and of huge importance. With it the reputation of Tito and the whole Government in the country and abroad has improved." Dedijer writes that Djilas also said: "With this verdict they have silenced us and the foreign countries" and "this solution could only be found by clever Tito."41 Dedijer himself later stated: "Tito destroyed him (Djilas - N. M.) so that he would make concept for the East. He came to him perfectly." ${ }^{42}$

The trial and the verdict were mainly received favorably in the West. The British Embassy characterized the verdict as mild, adding that both Djilas and Dedijer had some connection with "certain western circles." 43 Phillips wrote Tito a letter that he copied and gave to the members of Socialist International. In it he salutes the verdict stating that they "felt relief regarding the outcome of the trial." However, he did protest over the fact that Djilas had not received his veteran's pension. In his letter he writes that "there could be found some sort of funding so that he could make a decent living." When it comes to foreign policy, he objected the approach to the USSR by writing that Yugoslavia had gone back to the "evil ways of the Cominform countries." By giving Djilas a pension, according to Phillips, it would be a sign that "you can (Tito - N. M.) in your relations, show the world the basic superiority of a socialist system." Tito agreed and Djilas got his pension. This gesture did not remain unnoticed. Ante Radojević, traffic minister in the Kingdom of Serbs, Croats and Slovenes, had an interesting viewpoint of whole case. The pension of 40,000 dinars he saw as a key sign that Tito supported Djilas. Also, he speculated that through all the disagreements in the Politburo, Tito and Djilas were more open to West, while and Kardelj was more inclined toward the East and that the aim of it all was to "sit on two chairs." Also, he said that Djilas was a socialist and that he was connected to the labourists and the Socialist International. In order not to destroy his established friendship with the Labourists, Tito gave Djilas a suspended sentence, a pension, and "allowed him to work." ${ }^{\text {"4 }}$ We find a similar view in the speech made by Aleksandar Ranković at the Fourth Plenum: "In the West they wrote that our reaction at the Plenum (Third - N. M.) confirmed Yugoslavia's new orientation toward the East, still, from there they spoke loudly that the Third Plenum was proof that we had stepped deep into western waters." ${ }^{45}$

${ }^{40}$ K. Nikolić i S. Cvetković, Rađanje jeretika: suđenje Milovanu Đilasu i Vladimiru Dedijeru $1955,158$.

${ }^{41}$ AJ, 837, KPR, II-4-a/116, Izveštaji, informacije, beleške, pisma i pisanje štampe o slučaju Milovana Đilasa. Stav Jugoslovenske političke emigracije u vezi slučaja Đilas.

${ }^{42}$ Momčilo Đorgović, Đilas, vernik i jeretik (Beograd: Akvarijus, 1989), 250.

${ }^{43}$ Yugoslavia: Political Diaries 1918-1965, vol. 4: 1949-1965, 622-623.

${ }^{44}$ AJ, 837, KPR, II-4-a/116, Izveštaji, informacije, beleške, pisma i pisanje štampe o slučaju Milovana Đilasa. Stav Jugoslovenske političke emigracije u vezi slučaja Đilas.

${ }^{45}$ AJ, 837, KPR, Plenarne sedniceCK KPJ 1948-1978 II/11, Izlaganje Aleksandra Rankovića na Četvrtom plenumu. 
Bevan was passive. He had not involved himself directly into the case, but he and Lee were satisfied with the mild sentence. In the Yugoslav Embassy in London, Lee inquired whether she could send gifts to Djilas and Dedijer, but the answer was negative. They had hosted Dedijer's wife when she visited London. ${ }^{46}$

Other parties reacted as well. The Norwegian socialists said the case would have a negative impact, not because of the support for Djilas and Dedijer, but because of the attack on the opposition, which gave new arguments to the case. Fin Mone said that Djilas deserved such a fate because he went against his own country. ${ }^{47}$ Swedish socialist Björk stepped out and said that Djilas's ideas were impossible but he also objected to the treatment of Djilas and Dedijer. ${ }^{48}$

The French socialists issued an article about Djilas: "It is known that Yugoslavia has built its society on a single-party system and that a truly democratic spirit is expected to strengthen and develop." "49 Guy Mollet said that a multi-party system in Yugoslavia was simply not necessary. ${ }^{50}$ In Germany they observed the whole case passively, while the syndicate of the party that was under the strong influence of the British labourists, pledged their involvement. ${ }^{51}$ The leader of German socialists, Erich Ollenhauer, pointed out that they would not interfere in Yugoslavia's domestic affairs and that the case of Djilas and Dedijer was a domestic issue. ${ }^{52}$ His attitude was confirmed by Hans Kroll, the German ambassador in Yugoslavia, who said the moment the case had emerged it would not affect their relations. ${ }^{53}$

The harshest attitude toward Djilas and Dedijer was expressed by Swiss socialist Julius Humbert-Droz, who said their acts were “...purposely planned to discredit Yugoslavia with one great provocation". Still, he was against taking action. ${ }^{54}$ A similar opinion was expressed by the president of their party, Walther Bringolf, who connected the case to Tito's journey to India and Burma. ${ }^{55}$ In addition to Humbert-Droz, the most correct reaction was among the socialists of

${ }^{46}$ AJ, 507, SKJ, IX, S/c-408, Komisija za međunarodne odnose i veze: Razno.

${ }^{47}$ DA MSP, PA, 1955, Norveška, f-45, 314/a, Razgovori naših predstavnika u Norveškoj: Zabeleška o razgovoru Uvalića sa Fin Mone-om; Zabeleška o razgovoru Uvalića sa A. Andersonom.

48 DA MSP, PA, 1955, Švedska, f-67, 314/a, Razgovori naših predstavnika sa predstavnicima Švedske: Zabeleška o razgovoru I sekretara Poslanstva Benka-Vlade, sa Kaj Bjorkom 18. januara 1955.

${ }^{49}$ AJ, 507, SKJ, IX, S/c-413-414, Komisija za međunarodne odnose i veze: Razno.

${ }^{50}$ DA MSP, PA, 1955, Francuska, f-18, 314/a, Razgovori naših predstavnika u Francuskoj: Zabeleška o razgovoru Price sa Gi Mole-om, 13. 01. 1955.

${ }^{51} \mathrm{AJ}, 507, \mathrm{SKJ}, \mathrm{IX}, \mathrm{S} / \mathrm{c}-413-414$, Komisija za međunarodne odnose i veze: Razno.

${ }^{52}$ DA MSP, PA, 1955, Nemačka, f-42, 314/a, Razgovori naših predstavnika u Nemačkoj: Zabeleška o razgovoru Ambasadora FNRJ u Bonu, dr. Mladena Ivekovića sa pretsednikom SPD Olenhauer-om, 04. januara 1955.

${ }^{53}$ AJ, 837, KPR, I-5-b/82-2, Zabeleška o razgovoru državnog podsekretara dr. Beblera sa nemačkim ambasadorom g. Krol-om, na dan 14. januara 1955. godine. Razgovoru prisustvovao drug Zemljak.

${ }^{54}$ AJ, 507, SKJ, IX, S/c-413-414, Komisija za međunarodne odnose i veze: Razno.

${ }^{55}$ DA MSP, PA, 1955, Švajcarska, f-66, 314/a, Razgovori naših predstavnika u Švajcarskoj: Zabeleška o razgovoru prilikom posete i ručka kod V. Bringolf-a, 21. 01. 1955. Razgovor vodio R. Cacinović. 
Belgium, who only transmitted agency news and had no comments about the case and by doing so continued their harmonious relations with the SAWPY. ${ }^{56}$

The socialists of Italy and Austria could not pass up the chance to attack Yugoslavia. In these countries the socialist press was basically no different than the conservative. The Austrians went even further: they were skeptical toward Djilas's party, which had never actually been formed, because it was designed along the labourist model. In their opinion, that party should have been formed on the ideas of Austro-Marxism. ${ }^{57}$ The Dutch socialists also stepped in and used the case to attack Yugoslavia and its regime and pointed out that that was the reason they did not have any relations with the SAWPY.

During the 1 of May celebration, the chairman of the Labor Party of the Netherlands, Vermeer, said in his speech that behind the Iron Curtain there were two countries where there was dictatorship and no trace of human rights: Franco's Spain and Tito's Yugoslavia. Minister Ristić concluded: "With the case of Djilas and Dedijer, Hendrik Vos and others had obtained new material to condemn the dictatorship and the single-party system". 58 The opinion of the Dutch socialists was also present in Denmark in a milder form, where the trial had left a negative effect. ${ }^{59}$ Of course, Topalović did not miss his chance. As we have seen, he supported Djilas from the very start. Now, as Paris magazine Combat writes "the Democratic union of Serbs, Croats and Slovenians" salutes the actions of Djilas and Dedijer. ${ }^{60}$

In addition to party reactions, the case was represented in the press, especially the conservative press, which used the opportunity to address the connections of the European socialists with Yugoslavia. ${ }^{61}$ The British Times wrote daily about the case while the BBC in its program for Eastern Europe broadcast 8 to 10 programs daily. ${ }^{62}$ In his notes, Moše Pijade noted emotionally that the aim of the campaign was to discredit Yugoslavia in the very moment when Tito's reputation had grown with his visit to India and Burma. About the nature of the campaign, he wrote: "It is a whole paper counter-revolution!",63 The counterrevolution was yet to come with further changes in Yugoslavia's foreign policy and the further development of the Djilas case.

\footnotetext{
${ }^{56}$ AJ, 507, SKJ, IX, S/a-31, Komisija za međunarodne odnose i veze: Sednice komisije 1950-1955.

${ }^{57}$ AJ, 507, SKJ, IX, S/c-413-414, Komisija za međunarodne odnose i veze: Razno.

58 DA MSP, PA, 1955, Holandija, f-23, 314/a, Razgovori naših predstavnika u Holandiji; DA MSP, PA, 1955, Holandija, f-23, 322, Političke posete.

${ }^{59}$ DA MSP, PA, 1955, Danska, f-12, 314/a, Razgovori naših predstavnika u Danskoj: Zabeleška o razgovoru drugova S. Pustinjaka i S. Mladenovića sa A. Andersen-om, potpredsednikom I. O, Karison-om, sekretarom socijaldemokratske partije Danske, na dan 11. maja 1955.

${ }^{60}$ Политика, 4. 1. 1955.

${ }^{61}$ Borba, 4. 1. 1955.

${ }^{62}$ AJ, 837, KPR, I-5-b/120-2, Zabeleška razgovora A. Beblera sa F. Robertsom, ambasadorom UK na dan 21. 1. 1955, prisutni M. Sardelio.

${ }^{63}$ AJ, 513, MP, XXXIX MP, III-3/146, Izgradnja nove Jugoslavije, 1944-1964, Slučaj Milovana Đilasa i Vladimira Dedijera, sa propratnim materijalom, Beleška.
} 


\section{Imprisonment of the Dissident and Western Reactions}

In the shadow of major foreign policy changes, the Djilas case received even greater significance. With the Belgrade and Moscow declaration, relations between Yugoslavia and USSR had improved. From Yugoslavia's point of view, the improvement was looked upon as positive because it meant independence from the West. However, with clever maneuvering by Nikita Khrushchev, Yugoslavia was day by day being drawn closer to the Eastern bloc. With a series of masterful "coincidences" Yugoslavia was part of the Eastern bloc and was getting more and more involved into the then main problem: the Hungarian crisis. Tito tried his best to get out of that "diplomacy grip." ${ }^{64}$

In that situation where the Non-Alignment movement was tested, the Djilas case emerged again. In an article in the New Leader "Storms in Eastern Europe" ("Bure u Istočnoj Evropi") Djilas supported the Hungarian revolutionaries, which was not surprising considering the fact that they shared common ideas. Yugoslavia's attitude was a de facto support for the intervention but it was also a matter of "right turn" that "in the name of socialism" should be regarded with reserve. ${ }^{65}$ Djilas was against Yugoslavia's position and said that: "With the Hungarian revolution, a new era has begun in the history of mankind. Yet the Yugoslav Government has taken an ambiguous attitude toward this encouraging event; it was incapable of freeing itself from its ideological and bureaucratic class interests in foreign policy and abandoned the principle of equality and non-interference in the internal affairs of others." ${ }^{.66}$ The article was surely in line with Western politics about the whole issue.

The article was written at the right moment and with the right attitudes (for Western interests in the Hungarian revolution) and was also published in a series of socialist papers: The Tribune in Great Britain, the Arbeiderbladet in Norway, the Arbeiter zeitung and Zukunft in Austria, and Het Patrol in the Netherlands. ${ }^{67}$ Khrushchev himself addressed the article: "Where modern revisionism leads is visible on the example of Milovan Djilas, as well as Imre Nagy, who had completely abandoned the idea of socialism". ${ }^{68}$

Three days after the article had been published Djilas was arrested and sentenced in a secret trial to three years in prison in December of 1956. The verdict was undoubtedly shaped by Yugoslavia's foreign policy interests. This time a suspended sentence, the balance between punishing the dissident and satisfying the West, was not an option. The West did not pass up its chance to

\footnotetext{
${ }^{64}$ Lj. Dimić, Jugoslavija i Hladni rat: Ogledi o spoljnoj politici Josipa Broza Tita (1944-1974), 226.

${ }^{65}$ Ibid, 232.

${ }^{66}$ K. Nikolić i S. Cvetković, Rađanje jeretika: suđenje Milovanu Đilasu i Vladimiru Dedijeru $1955,60$.

${ }^{67} \mathrm{AJ}, 837$, KPR, II-4-a/116, Izveštaji, informacije, beleške, pisma i pisanje štampe o slučaju Milovana Đilasa.

${ }^{68}$ Tajms, London, 7. novembar 1957. Navedeno prema: K. Nikolić i S. Cvetković, Rađanje jeretika: suđenje Milovanu Đilasu i Vladimiru Dedijeru 1955, 460.
} 
use the verdict as pressure. The arrest prompted an anti-Yugoslav campaign in the conservative as well as socialist press.

One of the first protests was from the New Leader which was ready to send a lawyer and demanded the right to observe the trial. Of course, it was all refused as an attempt of foreign interference in Yugoslavia's internal affairs. ${ }^{69}$

Interestingly, Bevan did not act directly. This is due to the fact that he was chosen as a Labor Foreign Minister in the Shadow cabinet so his political acts had to be more careful and rational. However, Lee visited Belgrade and had a chance to talk to Tito, Kardelj, Bakarić and Milentije Popović. When she returned to London she wrote an article for The Tribune in which she attacked Yugoslavia's policy in the case Djilas. ${ }^{70}$ Talking about the arrest, Lee said: "In England oppositionists are expelled from the party, in Albania they are hanged, and in Yugoslavia they are arrested". ${ }^{71}$ Djilas thought that her talks in Belgrade had contributed to his milder sentence. ${ }^{72}$

The British labourists went even further: when Lee returned to London in December of 1956, they formed a delegation composed of the most prominent party officials: Gaitskell, Bevan, Watson, Herbison and Driberg. The idea was for the delegation to visit the Yugoslav Embassy in London and lodge an official protest over the arrest of Djilas. They assured the Yugoslav officials that the protest would not be in the media. From the Yugoslav side it was regarded as interfering into country's sovereignty and the entire delegation was rejected. ${ }^{73}$ And indeed, there were no traces of the incident in the press. ${ }^{74}$

In March of 1957, a Yugoslav Parliament delegation headed by Moše Pijade visited Great Britain. The delegation met with the labourists on two occasions: at the headquarters of the party and at a lunch in the Yugoslav Embassy, where all the leading members of the Labour Party were present. Bevan avoided both encounters and Lee, who was present, said that he was unwell. The talks were surprisingly pleasant, without any provocation regarding Hungary or Djilas. Yet, Gaitskell did ask whether something could be done for Djilas. ${ }^{75}$ Soon after the delegation returned to Yugoslavia Moše Pijade died. The Labour Party, nor the labour press, expressed no condolences, probably as a specific signal that the recent hospitality should not be taken seriously. ${ }^{76}$

${ }^{69}$ AJ, 837, KPR, II-4-a/116, Izveštaji, informacije, beleške, pisma i pisanje štampe o slučaju Milovana Đilasa. Stav Jugoslovenske političke emigracije u vezi slučaja Đilas.

${ }^{70}$ AJ, Fond 142, Socijalistički savez radnog naroda Jugoslavije (SSRNJ), Socijalističke partije Zapada 42-151, Materijali o saradnji SSRNJ sa socijalističkim partijama i progresivnim pokretima.

${ }^{71}$ DA MSP, PA, 1956, Engleska, f-19, 122/a, Socijalistička partija: Telegram Beblera, 8. XII 1956.

${ }^{72}$ М. Ђилас, Пад нове класе: повест о саморазарағу комунизма, 255.

${ }^{73}$ AJ, SSRNJ, 142-42-151, Socijalističke partije Zapada. Materijali o saradnji SSRNJ sa socijalističkim partijama i progresivnim pokretima.

${ }^{74}$ DA MSP, PA, 1957, Engleska, f-22, 122, Socijalistička partija i drugi socijalistički pokreti: Naši odnosi sa laburističkom partijom od kraja 1956. do danas.

${ }^{75}$ DA MSP, PA, 1957, Engleska, f-24, 322, Uzajamne političke posete: Poseta naše parlamentarne delegacije Velikoj Britaniji (5-15 mart 1957).

${ }^{76}$ AJ, 507, SKJ, IX, S/c-408, Komisija za međunarodne odnose i veze: Razno. 
At the Congress of the Socialist International, Bevan and Phillips addressed the issue of Djilas and used the opportunity to send a message to Yugoslavia. Bevan stated: "... it is necessary that we point out that the arrest and imprisonment of Milovan Djilas is not compatible with socialist principles... We must say to our Yugoslav friends that if they want to establish intimate relations that were present a couple years ago, they have to allow liberal thinking to be visible in Yugoslavia." Philips was especially harsh: "Djilas was the first Yugoslav to make contacts between Yugoslavia and the Labour party. It is a cruel ungraciousness that Djilas is now in prison, in the same cell where he was during fascism.",77

Bevan was persistent in avoiding addressing the case with the Yugoslav officials, but he was active indirectly. Interestingly, he was "caught" in Egypt where he had visited Nehru and during a banquet Ambassador Bogdan Crnobrnja asked him when he would visit Yugoslavia again. The essence of the question was almost certainly with regard to the case Djilas. Bevan answered directly: "I cannot do that, Vlado (Dedijer - N. M.) and Djilas are my good friends. Djilas is not just your affair". ${ }^{78}$

Thanks to a grant provided by Konni Zilliacus, Dedijer was in London and held a lecture about Yugoslavia, of course with references to the Djilas case. He pointed out that Djilas had been released from prison during the new conflict between Tito and Khrushchev so that Tito would "show his teeth" as a signal to Moscow. ${ }^{79}$ Dedijer also glorified Tito and Yugoslavia. He pointed out that it was not yet time for multi-party system, that he did not support Djilas's ideas because other parties would become a base for all the opposition. Bevan stepped up confronting Dedijer and defending Djilas's ideas. The lecture was not without its controversies. Dedijer had received permission to leave the country provided he would not get involved politically, which is exactly what he did with the support of the labourists. Not only that, but he discussed Yugoslavia's current political issues and on Bevan's initiative was an active participant of the Labour Party's Foreign Affairs Board. ${ }^{80}$

Not heeding Vlahović's answer to Phillips, Gaitskell visited Yugoslavia in August of 1957. He addressed the issue of Djilas but also stated that the actions of the labourists were driven by Djilas's personal friendship with Bevan. The visit itself did not have any particular impact. ${ }^{81}$

The British labourists aimed to use their influence to involve other European socialists into the Djilas case. In the archives there is evidence that they intervened with the socialist parties of Belgium, Germany and Sweden, and we

\footnotetext{
${ }^{77}$ AJ, 507, SKJ, IX, S/a-1-63, Komisija za međunarodne odnose i veze: Sednice komisije 1950-1955.

78 DA MSP, PA, 1957, Engleska, f-24, 322, Uzajamne političke posete: Telegram Crnobrnje, 1. IV 1957.

${ }^{79} \mathrm{~V}$. Dedijer, $n$. d., 45.

80 AJ, 507, SKJ, S/a-1-63, Komisija za međunarodne odnose i veze: Sednice komisije 19501955; DA MSP, PA, 1957, Engleska, f-24, 314/a, Razgovori naših predstavnika u inostranstvu: Zabeleška o razgovoru B. Gorjana sa K. Zilijakusom dana 6. juna 1957.

${ }^{81}$ AJ, 507, SKJ, IX, S/a-63, Komisija za međunarodne odnose i veze: Sednice komisije 1950-1955.
} 
can assume that they also did the same with the other parties. ${ }^{82}$ These three parties refused to join the initiative stating that they did not want to interfere in Yugoslavia's internal affairs. ${ }^{83}$

We can perceive the reactions of the French socialists on the case through a conversation between Mustafa Vilović and André Philip, who said he was representing his whole party. He disagreed with the verdict and the trial, especially its secrecy, but at the same time he denounced Djilas's ideas, adding that he disapproved the anti-Yugoslav campaign in the West because he understood its political background. ${ }^{84}$ Consequently, in the French press the case was not so represented and the French socialists were not engaged directly in the case ${ }^{85}$ It is important to note that in this period the French socialists had made contact with the Communist Party of the USSR during their visit to the USSR and had favorable impressions. By doing so they established different politics from the other European socialists so that even their membership in the Socialist International was briefly in question. ${ }^{86}$ The Socialist Government of Guy Mollet was the only government in the West that had looked favorably on the reconciliation between Tito and Khrushchev. ${ }^{87}$ Still, relations with the French socialists, which could have had a bright future, were shattered by the colonial issue that had started with Tito's visit to India and Burma. Support for Nasser's nationalization of the Suez Canal had left its impact on these relations. ${ }^{88}$ In fact, the key question was the support for Algerian revolutionaries (FLN) that was a great blow to the government of Guy Mollet and crushed all interparty relations. ${ }^{89}$

Unlike the French socialists, on whom the case had not left a profound impact, the sudden deterioration of interparty relations could be seen with the labourists of Norway. They said directly that they were "loosing sympathies" as

${ }^{82}$ An official of the Belgian socialists in conversation with Pekić said that the British labourists had intervened with all the European socialists on behalf of Djilas (DA MSP, PA, 1957, Belgija, f-8, 314/a, Razgovori naših predstavnika u inostranstvu: Razgovor Pekića sa Delkuse-om, pomoćnikom sekretara PSB, 23. 10. 1957).

${ }^{83}$ DA MSP, PA, 1957, Belgija, f-8, 314/a, Razgovori naših prestavnika u inostranstvu: Razgovor Pekića sa Delkuse-om, pomoćnikom sekretara PSB, 23. 10. 1957; DA MSP, PA, 1957, Nemačka, f-67, 122, Socijalistička partija i drugi soc. pokreti: Zabeleška o razgovoru Kvedera i savetnika Jovića sa prvacima SPD Olenhauer-om, Meliesom i Vehnerom, na večeri 15. 1. 1957; DA MSP, PA, 1957, Švedska, f-102, 122, Socijalistička partija: Telegram Baće-a 26. 2. 1957.

${ }^{84}$ DA MSP, PA, 1956, Francuska, f-24, 314/a, Razgovori naših predstavnika u Francuskoj: Zabeleška o razgovoru na večeri kod Mustafe Vilovića, ministra-savetnika sa Andre Filip-om, 20. 12.1956.

${ }^{85}$ AJ, SSRNJ, 142-42-151, Socijalističke partije Zapada. Materijali o saradnji SSRNJ sa socijalističkim partijama i progresivnim pokretima.

${ }^{86}$ AJ, 507, SKJ, S/a-1-42, Komisija za međunarodne odnose i veze: Sednice komisije 1950-1955.

${ }^{87}$ D. Bogetić, Nova strategija jugoslovenske spoljne politike: 1956-1961 (Beograd: Institut za savremenu istoriju, 2006), 131.

${ }^{88}$ More about Yugoslavia and the Suez Crisis in: Vladimir Petrović, Jugoslavija stupa na Bliski istok: stvaranje jugoslovenske bliskoistočne politike 1946-1956 (Beograd: Institut za savremenu istoriju, 2007); Александар Животић, Југославија и Суецка криза: 1956-1957 (Београд: Институт за новију историју Србије, 2008).

${ }^{89}$ D. Bogetić, Nova strategija jugoslovenske spoljne politike: 1956-1961, 131, 143. 
well as that the verdict had produced disappointment among the socialists". The whole Djilas case was represented in their magazine Arbeiderbladet. ${ }^{90}$ The reason was their antagonism toward the USSR that was especially represented in that party and the Djilas case was used as its reflection. Adding to this, Phillips had intervened that they should have taken action in the case. ${ }^{91}$

For the first time for Djilas, the benefit of the Swedish socialist had acted. Oprecht said he "hoped" this verdict would be similar to the first one - mild. His hope, as we later saw, was futile. Oprecht did not have any understanding for the Yugoslav socialists because he thought that Djilas was no danger to them but with his arrest their reputation would suffer. ${ }^{92}$ On the other hand, Humbert-Droz said nothing about the case and his standpoint was "essentially positive". 93

The labourists of the Netherland and the socialists of Austria were the most active in the anti-Yugoslav campaign. The campaign of these parties practically never stopped and with this verdict they got "new material". The magazine of the Austrian socialists, the Arbajtercajtung, stood out saying that: "...in the same moment when the historical mission of Yugoslavia had set fire to a great freedom struggle in the countries of Eastern Europe, their leader was put... behind prison walls and silenced by force". ${ }^{94}$ Although they never organized any concrete activity for Djilas, they always brought out the topic of Djilas's case in the Socialist International, as a means of conducting a negative campaign of course. ${ }^{95}$ The Dutch press said that the arrest was "Tito's offering to the Russians". 96

With the socialists of Italy the process was different - it led to closer relations. Matteo Matteotti, the general secretary of the PSDI, was in Yugoslavia and did not ask about Djilas. Adding to this, the party leader, Saragat expressed interest about worker cooperatives stating that "different democratic forms" are possible and that a multi-party system was not necessary. ${ }^{97}$

The Socialists of Germany were persistent: they did not interfere. The process of building relations with the SAWPY was going its own slow way. It was not until 1956 that they received an official call to visit Yugoslavia. ${ }^{98}$

The most favorable relations were those with the socialists of Belgium. As we have seen, they turned down the initiative of the British labourists. Relations between the two parties were so close that the SAWPY proposed to the Belgian socialists to make contacts with the communist parties of Eastern Eu-

\footnotetext{
${ }^{90}$ AJ, 837, KPR, II-4-a/116, Izveštaji, informacije, beleške, pisma i pisanje štampe o slučaju Milovana Đilasa. Stav Jugoslovenske političke emigracije u vezi slučaja Đilas.

${ }^{91}$ AJ, 507, SKJ, S/a-1-40, Komisija za međunarodne odnose i veze: Sednice komisije 1950-1955.

${ }^{92}$ DA MSP, PA, 1956, Švajcarska, f-109, 122/a, Socijalističke partije: Telegram Repića, 4. 12. 1956.

${ }^{93}$ AJ, 507, SKJ, S/a-1-37, Komisija za međunarodne odnose i veze: Sednice komisije 1950-1955.

${ }^{94}$ AJ, 837, KPR, II-4-a/116, Izveštaji, informacije, beleške, pisma i pisanje štampe o slučaju Milovana Đilasa. Stav Jugoslovenske političke emigracije u vezi slučaja Đilas.

${ }^{95}$ AJ, 507, SKJ, S/a-1-63, Komisija za međunarodne odnose i veze: Sednice komisije 1950-1955.

${ }^{96}$ DA MSP, PA, 1957, Holandija, f-9, Pisanje holandske štampe o FNRJ.

${ }^{97}$ DA MSP, PA, 1957, Italija, f-40, 122, Socijalistička partija: Zabeleška o razgovoru sa potpredsednikom vlade i liderom PSDI g. Saragat-om, 22. 2. 1957.

${ }^{98}$ AJ, 507, SKJ, S/a-1-40, Komisija za međunarodne odnose i veze: Sednice komisije 1950-1955.
} 
rope, a process that the SAWPY had started with the Belgrade declaration. Unsurprisingly, the answer was negative, stating that they were not ready for that type of cooperation yet. ${ }^{99}$ Still, they pointed out that the trial should have been public and the fact that it was not had damaged Yugoslavia's reputation. ${ }^{100}$

Unlike a suspended sentence, the imprisonment of Djilas provoked negative reactions even from friendly parties. Closely connected to that was the new position of Yugoslavia: the Hungarian crisis and the role of Yugoslavia was a "thorn in the side" of the West and its interests. Djilas and his article, his trial and imprisonment, were specific a means of pressure and also a specific means of "political communication" with the West. The treatment of Djilas, along with the campaign of his defenders from abroad, had a direct impact on Yugoslavia's foreign relations. The moment when the anti-Yugoslav campaign slowed down, a new affair emerged: the publishing of the book "The New Class".

\section{Unique Front - Reactions to "The New Class"}

Although the dissident himself was behind bars, his actions had shaken Yugoslavia, especially its international position. During the summer of 1957 Djilas sent a manuscript of his book "The New Class", ${ }^{101}$ which was published in December of $1957 .^{102}$

As far as the Western political establishment was concerned, "The New Class" was the right book, at the right time, from the "right" person. It is a critique of communism as an ideology and socialism as a system. Using his literary talent, as well as his profound knowledge of Marxist ideologies, Djilas attacked the essence of the ideology, not as an opponent, but far more effectively, from the position of someone inside the ideology itself, showing all its antagonisms. With it the West gained an ideological weapon that pierced the heart of the opposing bloc.

The book got huge publicity, which was expected in the context of the Cold War. In 1957 alone it had 14 editions: in English, Serbian, Russian, German, Dutch, Finish, French, Italian, Spanish, and Danish. ${ }^{103}$ As a side effect of its popularity, the book was used as an instrument by the conservative party in its attack against the socialist parties. With Djilas's critique of the socialist system, the stage was also set for the criticism of labour, social democracy, and western type socialism. The conservatives of Western Europe did not pass up their chance. British labourist Barbara Castle regarded the book as harmful for socialism as a whole. ${ }^{104}$ Norwegian labourists had the same opinion and refused

\footnotetext{
${ }^{99}$ Ibid.

${ }^{100}$ DA MSP, PA, 1957, Belgija, f-8, 122, Socijalistička partija: Pismo M. Javorskog Vlahoviću.

${ }^{101}$ Milovan Đilas, Nova klasa (Beograd: Narodna knjiga, 1990).

102 AJ, 507, SKJ, IX, S/c-418, Komisija za međunarodne odnose i veze: Razno.

103 Добрило Аранитовић, Милован Ђилас: библиографија са хронологијом живота и рада (Београд: Службени гласник, 2008), 354.

${ }^{104}$ DA MSP, PA, 1958, Engleska, f-24, 314/a, Razgovori naših predstavnika u inostranstvu: Zabeleška o razgovoru C. Joba sa Barbarom Kasl, članom Izvršnog komiteta LP, na koktelu u našoj ambasadi, 7. 8. 1957.
} 
to publish and promote the book. ${ }^{105}$ The same views were shared by Swiss socialist Oprecht. ${ }^{106}$

With "The New Class" the Djilas case reached its highest point. The author was sentenced to 7 more years in prison in another closed trial. The trial was of great interest to the Western media, conservative as well as socialist. ${ }^{107}$ Consequently, the reaction also reached its high point.

The leaders of that reaction were, unsurprisingly, the British labourists. With the book itself they were closely connected: the publisher had offered Bevan to write the preface, which he refused. ${ }^{108}$ Lee compared Djilas to a meteor that symbolized modern struggles and marked Tito's regime as stagnating. ${ }^{109}$ Interestingly, in his memoirs, Djilas says that Lee first advised him not to publish the book. ${ }^{110}$ In any case, the whole party joined in: the Labour Party's Executive Committee issued a "special resolution" disapproving the arrest of Djilas. ${ }^{111}$ In the party itself there were mutual disagreements: Castle attacked Phillips that he was wrong with his positive judgment of Yugoslavia. ${ }^{112}$

This time, hand in hand with the British labourists, were the labourists of Norway. The party, led by Håkon Lie, sent a protest letter regarding the arrest that came while the trial was ongoing and was in a sense a form of direct pressure. Vlahović answered sharply: they should not interfere in Yugoslavia's internal affairs in the same way that Yugoslavia does not interfere in the internal affairs of Norway. ${ }^{113}$ Yet, the damage had been done and interparty relations that had been built for years suddenly deteriorated. ${ }^{114}$

In October of 1957, the International Socialist Bureau issued an official protest resolution. The secretary of the International had made an attempt to give the resolution to the Yugoslav Embassy in London but was refused with on the grounds that it is an act of interference in Yugoslavia's internal affairs. ${ }^{115}$

Particularly harsh was the reaction of the Austrian socialists. At their November 1957 party congress, gestures of friendship were sent to Djilas and they concluded that with his arrest Yugoslavia had become a part of the East. The Resolution entitled "Conclusion for the Victims of Dictatorship" was adopted unanimously and published in the Bulletin of the Socialist International. ${ }^{116}$

\footnotetext{
${ }^{105}$ DA MSP, 1957, PA, Norveška, f-70, 322, Uzajamne političke posete: Zabeleška o razgovoru V. Rolovića sa A. Andersenom u Ambasadi FNRJ u Oslu, dana 2. 9. 1957.

${ }^{106}$ DA MSP, PA, 1957, Švajcarska, f-101, 122, Socijalistička partija: Telegram Repića 6. 9. 1957.

107 AJ, 507, SKJ, IX, S/c-420, Komisija za međunarodne odnose i veze: Razno.

${ }^{108}$ DA MSP, PA, 1958, Engleska, f-24, 323, Uzajamne partijske posete i saradnja: Telegram Vejvode 31. 12. 1958.

${ }^{109}$ AJ, 507, SKJ, IX, S/c-426, Komisija za međunarodne odnose i veze: Razno.

${ }^{110}$ M. Đilas, Vlast, 298.

${ }^{111}$ DA MSP, PA, 1957, Engleska, f-24, 323, Uzajamne partijske posete: Telegram Vejvode 19. 10. 1957.

112 AJ, 507, SKJ IX, S/a-65, Komisija za međunarodne odnose i veze: Sednice komisije 1950-1955.

${ }_{113}$ AJ, 507, SKJ, IX, S/c-421, Komisija za međunarodne odnose i veze: Razno.

114 AJ, SSRNJ, 142-42-151, Socijalističke partije Zapada. Materijali o saradnji SSRNJ sa socijalističkim partijama i progresivnim pokretima.

${ }^{115}$ AJ, 507, SKJ, IX, S/a-71, Komisija za međunarodne odnose i veze: Sednice komisije 1950-1955.

116 AJ, 507, SKJ, IX, S/a-66, Komisija za međunarodne odnose i veze: Sednice komisije 1950-1955.
} 
The Swedish and Swiss socialists had different attitudes. The magazine of the Swedish socialists wrote critically about Djilas and took a positive stance toward Yugoslavia. ${ }^{117}$ Particularly critical were the Swiss socialists. As we saw, Oprecht had a negative view of the "The New Class". Droz aimed directly: "...does this mean that workers cooperatives were an element of democracy when Djilas held one of the most important and influential positions in the state and the party, and then stopped being that when he was eliminated?"118

The socialists of Belgium were traditionally positive toward Yugoslavia, while this was not the case with the socialists of the Netherland and Denmark. A certain ignorance was noticeable among the socialists of Italy, which is probably a consequence of the official relations that the two parties established in 1957. The German socialists were persistent: they regarded the issue as Yugoslavia's internal affair and resisted the pressure from the British labourists to act. Still, due to the recognition of East Germany the same year, relations between the two parties suffered greatly, while the Djilas case in October of 1957 was sidelined. ${ }^{119}$

The new moment came from an unexpected side, but was deeply connected with the Djilas case. The so-called Krekić-Pavlović socialist group was tried in February and March of 1958 for "hostile activities." Paradoxically, the Djilas case reached its peak with this trial and willingly or not, Djilas was ended up in the same context with the pre-war socialists and even Chetnik emigrants. ${ }^{120}$ The trial caused turmoil among the European socialists, the culmination of the whole dispute that was present from the first contacts. The Socialist International issued a protest against the "vicious verdicts" stating that Krekić and Pavlović were "socialists and pioneers of syndicalism" and that the fact that they were convicted for "expressing criticism allowed in democracy" was proof that there was a dictatorship in Yugoslavia. ${ }^{121}$

Again in the anti-Yugoslav campaign the leaders were the British labourists. They acted directly and through the Socialist International and named their campaign "world protest against the conviction of old people". ${ }^{22}$ They issued a special memorandum for Tito in which they said: "Lately we are worried because of the arrests and imprisonments of people of international reputa-

117 Ibid.

118 AJ, 507, SKJ, IX, S/c-423, Komisija za međunarodne odnose i veze: Razno.

119 AJ, SSRNJ, 142-42-151, Socijalističke partije Zapada. Materijali o saradnji SSRNJ sa socijalističkim partijama i progresivnim pokretima.

${ }^{120}$ At the beginning of the Djilas case in 1954, the political emigrants were interested in the case. They followed, commented the case, while the Association of Serb Chetniks in London sent a letter of support for Djilas (AJ, 837, KPR, II-4-a/116, Izveštaji, informacije, beleške, pisma i pisanje štampe o slučaju Milovana Đilasa. Stav Jugoslovenske političke emigracije u vezi slučaja Đilas). More about connections with the political emigration in: Мира Радојевић, „Милован Ђилас и српска политичка емиграција (1954-1995)“, Токови историје, бр. 4, (2007), 118-134.

121 AJ, SSRNJ, 142-42-151, Socijalističke partije Zapada. Materijali o saradnji SSRNJ sa socijalističkim partijama i progresivnim pokretima.

122 DA MSP, PA, 1958, Engleska, f-23, 122, Socijalistička partija i drugi socijalist. pokreti: Telegram Vejvode, 25. 2. 1958. 
tion in the socialist movement. With all due respect we appeal that you give amnesty in the spirit of love for the freedom that sparked the antifascist revolution in March of 1941. The people we are referring to are: Milovan Djilas, partisan general and former vice president, Bogdan Krekić, former general secretary of the Yugoslav unions and founder of the Socialist party, and Aleksandar Pavlović former vice president of the former Socialist Party of Yugoslavia."123

The appeals were in vain. As we know, Krekić and Pavlović were convicted, Dedijer's visa was revoked and Djilas was still behind bars. Yet, the treatment of Djilas in 1958 improved, which he believed was connected with the realization by the prison authorities that he could not be crushed with solitary confinement. ${ }^{124}$ His improved treatment had a positive, albeit limited reception in the West. ${ }^{125}$

The parties of the Netherland, Denmark, Italy, Austria, and Norway had received new material for their anti-Yugoslav campaign. The parties of Switzerland and Belgium had a milder attitude because they had understanding for the verdict but not for the refusal of the commission of the Socialist International. The Socialists of France and Sweden also supported Krekić and Pavlović. With the socialists of Germany, the situation was specific: they did not interfere with the trial but at the same time they did not object to the decision of the International. ${ }^{126}$

The circle was closed in 1958. Relations with the European socialists were similar to those in 1948: full of antagonism, mistrust and hostility. The Djilas case reached its peak in the same year when the case of Krekić and Pavlović burned the bridge to the West that had been built, among others, by Djilas himself. ${ }^{127}$

$* * *$

The dynamic relations with the European socialists, built mainly by Djilas, by his dissidence, had suffered significantly. Promoting social democracy and condemning it by the government could not have allowed the European left and the Socialist International to remain passive.

${ }^{123}$ D. Bogetić, Nova strategija jugoslovenske spoljne politike: 1956-1961, 238-242.

${ }^{124}$ M. Đilas, Vlast, 301; Milovan Đilas, Tamnica i ideja (London: Kolašinska liga za ljudska prava, 1984), 38, 62.

${ }^{125}$ DA MSP, PA, 1958, Norveška, f-84, 122, Socijalistička partija: Telegram Čatipovića, 16. 9. 1958.

126 AJ, 507, SKJ, S/a-1-78, Komisija za međunarodne odnose i veze: Sednice komisije 19501955; DA MSP, PA, 1958, Belgija, f-9, 122, Socijalističke partije i drugi socijalistički pokreti: Telegram Javorskog 19. 04. 1958; DA MSP, PA, 1958, Švajcarska, f-122, 122, Socijalistička partija i drugi socijalistički. pokreti: Telegram Kos-a, 24. 2. 1958; DA MSP, PA, 1958, Nemačka, f-82, 122, Socijalistička partija: Telegram Kljuna, 7. 3. 1958; DA MSP, PA, 1958, Švedska, f-124, 122, Socijalistička partija: Telegram Bače, 9. 4. 1958; DA MSP, M. O, 1958, f-75, 610, Socijalistička internacionala: Zabeleška o poseti pretsednika Socijalističke internacionale i p. pretsednika Socijaldemokratske partije Danske A. Andersena Ambasadoru Lj. Iliću na dan, 7. 2. 1958.

${ }^{127}$ AJ, 837, KPR, I-1/1363. Depeša jugoslovenskog ambasadora u Velikoj Britaniji Ive Vejvode Kabinetu Pretsednika Republike, 1. avgust 1958; Navedeno prema: D. Bogetić, Nova strategija jugoslovenske spoljne politike: 1956-1961, 242. 
However, the background of the reaction was far more complex. In parallel with the Djilas case, a new Yugoslav policy started taking shape: The NonAligned Movement, which was often opposed to the interests of the countries of Western Europe. Non-Alignment took its greatest toll on relations with the British labourists, who had led the campaign for Djilas.

The fate of Djilas had its Cold War dimensions and interference on his behalf by the European socialists was a specific instrument of diplomatic pressure on Yugoslavia. When Yugoslavia's new policy was established in 1958, the Djilas case had reached its peak and all of the parties of the European left had objected to his treatment, and by so doing, damaged their relations with Yugoslavia, which had been established after 1948.

\section{REFERENCES}

- Aranitović, Dobrilo. Milovan Đilas: bibliografija sa hronologijom života $i$ rada. Beograd: Službeni glasnik, 2008.

- Bekić, Darko. Jugoslavija u Hladnom ratu: Odnosi sa velikim silama 19491955. Zagreb: Globus, 1988.

- Bogetić, Dragan. Koreni jugoslovenskog opredeljenja za nesvrstanost. Beograd: Institut za savremenu istoriju, 1990.

- Bogetić, Dragan. Nova strategija jugoslovenske spoljne politike: 1956-1961. Beograd: Institut za savremenu istoriju, 2006.

- Dedijer, Vladimir. Veliki buntovnik Milovan Đilas: prilozi za biografiju. Beograd: Prosveta, 1991.

- Dimić Ljubodrag. Jugoslavija i Hladni rat: Ogledi o spoljnoj politici Josipa Broza Tita (1944-1974). Beograd: Arhipelag, 2014.

- Đilas, Milovan. Vlast. London: Naša reč, 1983.

- Đilas, Milovan. Nova klasa. Beograd: Narodna knjiga, 1990.

- Đilas, Milovan. Tamnica i ideja. London: Kolašinska liga za ljudska prava, 1984.

- Đilas, Milovan. Pad nove klase: povest o samorazaranju komunizma. Beograd: Novinsko-izdavačka ustanova Službeni list SRJ, 1994.

- Đorgović, Momčilo. Đilas, vernik i jeretik. Beograd: Akvarijus, 1989.

- Geler, Mihail i Aleksandar Nekrič. Utopija na vlasti: istorija Sovjetskog Saveza. Podgorica: CID, 2000.

- Kovačević, Branislav. Đilas heroj-antiheroj: iskazi za istoriju. Podgorica: Pobjeda, 2006.

- Mijatov, Nikola. „Milovan Đilas i britanski laburisti 1950-1955“. Istorija 20. veka, br. 2, (2015), 27-43. DOI: 10.29362/ist20veka.2015.2.mij.27-43

- Miletić, Aleksandar V. "Unrealised Nordic Dream`: Milovan Đilas and the Scandinavian Socialists". Tokovi istorije, br. 3, (2015), 89-106. DOI: 10.31212/tokovi.2015.3.mil.89-106

- Nikolić, Kosta i Srđan Cvetković. Rađanje jeretika: suđenje Milovanu Đilasu i Vladimiru Dedijeru 1955. Beograd: Institut za savremenu istoriju, 2011. 
- Petrović, Vladimir. Jugoslavija stupa na Bliski istok: stvaranje jugoslovenske bliskoistočne politike 1946-1956. Beograd: Institut za savremenu istoriju, 2007.

- Radojević, Mira. „Milovan Đilas i srpska politička emigracija (1954-1995)““. Tokovi istorije, br. 4, (2007), 118-134.

- Unkovski-Korica, Vladimir. "The Yugoslav Communists' Special Relationship with the Britih Labour Party 1950-1956". Cold War History, vol 14. no. 1, (2014), 23-46. DOI: 10.1080/14682745.2013.765864

- Yugoslavia: Political Diaries 1918-1965, vol. 4: 1949-1965. Edited by, R. L. Jarman. Oxford: Archive Editions, 1997.

- Životić, Aleksandar. Jugoslavija i Suecka kriza: 1956-1957. Beograd: Institut za noviju istoriju Srbije, 2008.

NIKOLA MIJATOV, MA, Research Assistant

Institute for Contemporary History

Belgrade, Republic of Serbia

nikolamijatov@gmail.com

\author{
THE CASE OF MILOVAN DJILAS \\ AND THE EUROPEAN SOCIALISTS 1954-1958
}

\begin{abstract}
Summary
Milovan Djilas, one of the Politburo members specifically responsible for relations with the European socialists, had abandoned Communism and called for the creation of another, social democratic party in Yugoslavia. With the prosecutions of Djilas, social democracy as an idea was also being criticized by the Yugoslav Government. Consequently, the European member parties of the Socialist International intervened on Djilas's behalf, and indirectly defended social democracy. The British labourists, among them primarily Aneurin Bevan, were mostly involved in the case and the most active in the defense of Djilas. Other parties followed close by with each new trial of Djilas and his imprisonment. Finally, in 1958, after the trial for his book "The New Class," all of the European socialist parties were united in their criticism of Yugoslavia and the treatment of the now dissident Djilas. The causes were more complex, though. In those years Yugoslavia was building its new Cold War position, later known as the Non-Aligned Movement, and by doing so, distancing itself from Western Europe. The case of Djilas, and the reactions of the European socialists, was merely a reflection of that process. Furthermore, the interventions by the European socialists on behalf of Djilas were a form of specific political pressure on Yugoslavia. Still, the interventions were in vain. Yugoslavia pursued its new role as a non-aligned country and also kept Djilas firmly behind bars.
\end{abstract}

KEYWORDS: Milovan Djilas, European Socialists, Dissidence, New Class 